\author{
Carla Marcela Acosta Smith \\ BES, York University, 2012 \\ A Major Research Paper \\ presented to Ryerson University \\ in partial fulfillment of the requirements for the degree of \\ Master of Planning \\ in \\ Urban Development
}

Toronto, Ontario, Canada, 2018

(C) Carla Marcela Acosta Smith 2018 
I hereby declare that I am the sole author of this MRP. This is a true copy of the MRP, including any required final revisions.

I authorize Ryerson University to lend this MRP to other institutions or individuals for the purpose of scholarly research.

I further authorize Ryerson University to reproduce this MRP by photocopying or by other means, in total or in part, at the request of other institutions or individuals for the purpose of scholarly research.

I understand that my MRP may be made electronically available to the public. 


\title{
GRAVE CONCERNS: CAPTURING RELIGIOUS DIVERSITY IN CEMETERY PLANNING
}

\author{
(C) Carla Marcela Acosta Smith, 2018
}

\author{
Master of Planning \\ in \\ Urban Development \\ Ryerson University
}

\begin{abstract}
It has been estimated that the remaining cemetery land in Toronto will run out of space within the next 30 years. Although death is the only certainty we have in life, planners aren't planning for it. Toronto's population is increasingly aging, growing, and diversifying, which makes this an issue that can longer be ignored. There are 23 active cemeteries in Toronto, of which only 13 are non-denominational cemeteries that are able to capture the religious diversity for accommodating the deceased. Through this paper, it is found that cemeteries not only provide an essential public service, but they also play an important role in anchoring immigrant communities. Through exploratory research methods, findings suggest that those religions that require in-ground burial will face the brunt of accessing affordable cemetery services in Toronto. Recommendations are made to address this land use policy gap and calls for action to increase supply within existing cemetery lands in Toronto so that cities are not only planned for the living, but also for the dead.
\end{abstract}

Key words: cemetery; diversity, religion; immigration; land use; death sprawl, Toronto 


\section{ACKNOWLEDGEMENTS}

I owe this work to the many people who have supported me through my studies and I would like to express my sincere appreciation for the following persons, because without them this work would have not been possible

Firstly, I'd like to give my sincere appreciation and thanks to my Supervisor Dr. Zhixi Cecilia Zhuang for your mentorship, support, feedback, and encouragement me through this process. Thank you very much for your help in guiding me through this complex topic and for sharing your enthusiasm with me. I'd also like to thank Nina-Marie Lister and Nicole Hanson for all of your feedback and insight on this topic.

To my parents thank you so much for all of your support, love, and sacrifices that helped me get to where I am today. You are my biggest cheerleaders and I'm so happy to share this success with you. My sister, thank you for always being so supportive and sending me all your positive vibes during this process.

Gaurav Bajaj, thank you so much for listening to me talk about cemeteries and visiting a few with me too! Thank you for all of your support and taking care of all of the little things for me so that I could focus on everything else. Can't thank you enough.

To my friends, Diana Radulescu, thank you for your enthusiasm in the topic and encouraging me through this process. I also sincerely appreciate the time you took to review my paper. Marina Saad, thank you for those coffee chats at our local coffee spot. It was speaking with you that helped me decide on pursuing this topic, and I'm so glad that I did.

To my fellow classmates, thank you for sharing articles about cemetery planning and for being so encouraging while pursuing this topic.

I would also like to thank the rest of the faculty at the School of Urban and Regional Planning for making these past two years an incredible journey.

Thank you. 


\section{Table of Contents}

List of Tables vii

1.0 Introduction $\quad 1$

2.0 Literature Review 3

2.1 Societal Importance of Cemeteries $\quad 3$

2.2 Challenges and Issues Emerging for Planners $\quad 6$

2.3 Challenges for Planners in Toronto $\quad 8$

2.4 Choice and Equity for Accommodating the Deceased 10

3.0 Method 12

3.1 Limitations 16

$\begin{array}{ll}4.0 \text { Context } & 16\end{array}$

4.1 Cemetery Lands in Toronto 16

4.1.1. Evolution of Cemeteries in Toronto 16

4.1.2 Current Cemetery Context in Toronto 19

4.1.3 The Cost of Cemetery Services in Toronto 23

4.2 Religion \& Immigration Trends 26

4.2.1 The Diversifying Religious Demographics in Toronto 26

4.3 Changing Consumer Tastes and Preferences Impacting the Cemetery Industry 29

5.0 Planning Policy Context $\quad 30$

5.1 Policy Planning Framework $\quad 30$

5.1.1 The Planning Act $\quad 31$

5.1.2 Ontario Heritage Act 32

5.1.3 Provincial Policy Statement 33

5.1.4 Growth Plan for Greater Golden Horseshoe 34

5.1.5 Greenbelt Plan $\quad 35$

5.1. 6 City of Toronto Official Plan 36

6.0 Findings \& Implications $\quad 37$

6.1 Limited Provincial Policy Guidance for Cemetery Development 38

6.2 Interjurisdictional Death Sprawl $\quad 41$

6.3 Social and Economic Inequalities 42

6.4 Spirituality Vs. Religion Influence on Cemetery Industry 47 
$\begin{array}{ll}6.5 \text { Anchoring immigrant communities } & 48\end{array}$

$\begin{array}{ll}7.0 \text { Recommendations } & 49\end{array}$

7.1 Provincial Guidance and Regional Coordination 49

7.2 Regional Strategic Plan for the GGH Area 51

7.3 Establish Criteria to Promote Intensification of Existing Cemeteries 52

7.4 Acquire Cemetery Development through Parkland Dedication 53

$\begin{array}{ll}9.0 \text { References } & 57\end{array}$ 


\section{List of Tables \& Graphs}

Table 1. Breakdown of Active and Not-Active Cemetery Organizational Breakdown

Table 2. Ownership Breakdown of Active Cemetery Type in Toronto

Table 3. Comparison of cemetery services from Mount Pleasant Group of cemeteries ${ }^{1}$ within Toronto and outside of Toronto

Graph 1. Population Growth Rate Projected in Canada 


\subsection{Introduction}

In Toronto, it is anticipated that the remaining cemetery land will be exhausted within the region in the next three decades (McGrath, 2016; Smee, 2016; City of Toronto, 2016; Queen, 2016). In a world where the only certainty in life is death, planners have significantly overlooked the need to anticipate for this important service. Existing literature identifies cultural and religious diversity as an important factor influencing the development and expansion of cemeteries (Bamajian \& Cotts, 2010; Nurse 2001; Bennett \& Davies, 2015; Francis et al., 2000; Ansari, 2007). However, there is very limited research that explores the connection between religion and cemetery planning, especially in the Toronto context.

Cemeteries provide an essential public service and play an important role in our urban fabric. Besides accommodating for the deceased, they also play an important role in anchoring immigrant communities. In 2016, immigrants represented 46.1\% of Toronto's population (Statistics Canada, 2017), and by 2056 immigration is projected to be the leading source of population growth in Toronto (Friesen \& Cardoso, 2017). As the newcomer population in Toronto is projected to rise, so will the mosaic of cultural and religious practices that they bring.

In a multi-faith city such as Toronto, understanding the connection between religious practices, death rituals, and its impact on the cemetery industry and planning for cemeteries can support informed land use decisions, policy direction, and responses in the cemetery industry. Thus, this exploratory research aims to understand how religious diversity informs the demand for cemetery development in land use planning in Toronto. It does so by answering the following research questions: How is Toronto's religious diversity being captured and addressed in the development or expansion of cemeteries in Toronto? What are the current challenges and opportunities to cemetery planning while dealing with various religious 
preferences? To answer these questions, a literature review, policy scan, and semi-structured interviews were conducted.

The research identified that private, non-denominational cemeteries respond to diverse needs by ensuring religious and cultural competence around different death practices and through the provision of services to meet those needs. Findings illustrate that competence needs to be complemented with an understanding of the unequal social and economic burdens that are inflated by limited supply of cemetery land. Groups requiring traditional burial methods to accommodate the deceased will be among those who will experience the brunt of accessing affordable cemetery services in Toronto.

Cemeteries provide an essential public service, yet land use planning policies give little recognition to the essential role cemeteries play in accommodating the deceased. The Provincial Policy Statement 2014 recognizes cemeteries as an institutional land use that supports and sustains the Provincial interest in achieving healthy, livable, and safe communities. Despite this recognition, other provincial plans view cemeteries as part of our cultural heritage landscape which provides limited considerations for how these land uses can be developed or expanded on. The City of Toronto identifies cemeteries as part of their open space and green network to be enjoyed by residents and visitors, rather than an essential public service needed to accommodate for the deceased.

Without improved guidance or mandate from the Province to develop, or expand and intensify existing cemeteries, pressure will be felt in surrounding municipalities as Toronto residents seek cemetery services outside of Toronto. Furthermore, establishing 'modern' cemeteries, averaging 63 hectares (Larkin, 2011) in urban cores, seems like an unlikely feat. Thus this paper argues that the conventional 
characteristics of cemeteries need to be re-imagined in order to identify additional opportunities for cemetery development within the urban core.

To address these identified issues, four recommendations are provided that suggest specific provincial and municipal actions to encourage the development and expansion of cemeteries in Toronto.

\subsection{Literature Review}

\subsection{Societal Importance of Cemeteries}

Cemeteries not only serve the purpose for accommodating the deceased, as this section will discuss, they are also spaces that hold a significant role in the lives of immigrant communities. As cemeteries become places where communities utilize to set roots in their new home, they also become part of a discourse that speaks to representation, access, and religious diversity in our shared cultural landscapes.

The diversity that propels people to use, value and view cemeteries is just as various as Toronto's population itself. Despite the multitude of preferences and practices across religions and cultures to accommodate the dead, there is always one thing in common: the need to recognize and honour the dead (Larkin, 2011). Across history, the method in which groups of people would accommodate the deceased have changed, and so has the perception and view of the meaning and functionality of cemeteries. Intimately tied to the perceptions of death and how we accommodate for the dead are religion and culture, which are also constantly changing. Thus, the function and meaning of cemeteries have evolved over time, 
and today their role within the urban fabric of a highly diverse backdrop of people plays a significant role in our society by providing a space that serves multiple functions, and holds different meanings and values.

Although the main purpose of cemeteries is to provide a space where families and friends can commemorate their loved ones, research studies have shown that these spaces serve multiple functions and meanings within the urban fabric of our cities. McClymont (2016) draws on stories from cemetery managers across England and Wales to assess the role cemeteries play in cities, to understand their spatial significance in order to better inform planning and management decisions that positively affect cemetery space within cities. McClymont argues that in light of the limited cemetery policy or research at both the local and national level, it is important to ensure that decision makers understand the role these spaces play in cities as a way to guide the development of new cemeteries and to manage existing ones. It was identified through the study that cemeteries provide a multifunctional space within the city by contributing to greenspace or green infrastructure, civic identity and local place attachment. Given the multiple roles and feelings that these spaces evoke make them more prominent compared to spaces in the city that don't offer as many roles within a city.

In a Norwegian case study (Evensen, et al. 2017), two cemeteries were studied to understand their everyday in urban spaces, where urban green spaces are becoming scarcer. In this study 18 different uses were identified in the cemeteries that were registered. Among the activities observed included walking dogs, biking, and exploring cultural heritage. This study showed how urban cemeteries are not used solely for visiting graves but also for recreational activities, transforming it into a multifunctional green space. The researchers anticipate that changing views on death and funerals, as well as the growing cultural and religious influences from an increasingly multicultural population in Norway could potentially lead to a larger role of cemeteries as urban green spaces. 
Francis et al, (2000) explore how cemeteries can sustain important and largely overlooked functions for personal, family, and community life by examining the user perspective influences in six cemeteries in London in order to understand the underlying meanings and use of cemeteries for different cultural and ethnic groups. The researchers visited these cemeteries, some religious and others nondenominational, to gain an understanding of the overall relationship of these groups to the cemetery. The study was aimed at enhancing the understanding of cemetery and grave visits at a time when there is a growing interest in British cemetery policy as managers and planners are considering different ways of using the limited space available for burial. It was found that family relationships are not the exclusive driving force behind frequent cemetery visits, regardless of the timing and reason for these visits. Based on the first-hand interviews with cemetery visitors, the researchers noted that cemeteries also provide personal and family support. This suggests, that cemeteries play an important role in anchoring families and creating an important connection between the past, the living, and future generations.

As Francis, et al. (2000) has identified, the cemetery industry has recently been discussing a variety of alternatives to accommodate the deceased. The industry is exploring methods such as grave recycling and natural burials, which have sparked a range of discussions on how to manage death and the burial process. However, according to Basmajian and Coutts (2011), the most profound factors that will influence death practices will be environmental concerns and changing demographics. This was also echoed in Longoria's (2014) research that highlighted a growing expectation for service providers and public administrators in Texas to be more "culturally competent". This means that people will eventually be able to influence the way in which service providers meet the needs of a changing demographic and to incorporate cultural understanding in the way that local governments manage cemeteries. 
Cemeteries play a variety of roles for different groups of people. For example, Toronto residents whose family history dates back several generations likely have family members buried in Toronto's cemeteries. This sense of connection to a cemetery space is vastly different than for someone who may not have any familial ties to Toronto cemeteries. This may be the story for many of Toronto's immigrant population and future immigrants. Today, immigrants comprise $46.1 \%$ of Toronto's population (Statistics Canada, 2017) and immigration is projected to be the main driver for population growth. If the existing non-denominational cemeteries are expected to capture the majority of new residents, many of which will be immigrants to Toronto, understanding what the barriers, challenges, and opportunities are will be important to ensure that there is an opportunity for everyone to have access to cemetery space in Toronto.

\subsection{Challenges and Issues Emerging for Planners}

As a profession, land use planning has only been focused on the modification of the built environment, but addressing the needs various religious groups is a complex task that urban planners currently have limited ability to influence. Yet, understanding the complexities of the different and changing religious traditions and practices impacting the demand for cemetery land is a matter that planners cannot continue to ignore.

Bamajian \& Coutts (2011) discuss key demographic, environmental, and land use issues that are related to accommodating the dead in United States and urge both planning researchers and practitioners to consider these within planning decisions. This research determined that in addition to environmental concerns impacting how cemetery practices are undertaken, changing demographics are also expected to impact the cemetery industry in profound ways. Bamajian \& Coutts predict that as the population of the United States continues to become increasingly diverse over the upcoming years, the different end-life 
requirements of intersecting religious and cultural affiliations will transform the current methods of cemetery service provision. It is anticipated that large cemeteries will respond to this pluralism by dedicating separate spaces to particular groups. In other areas where the expansion of cemeteries is limited, social groups have taken it upon themselves to develop their own burial spaces. As such, this potential change may bring us back to a more fragmented set of cultural, religious, and ethnic burial sites that resemble the burial grounds of the 19th century as expanded on in Section 4.1.1.

Projecting cemetery needs for future generations has been suggested by Coutts, et al (2011) as an important long-range land use planning exercise. The demand for cemetery space will become an important aspect of long-term planning decisions that need to sensitively take into account diverse set of social, cultural, and environmental expectations that will impact places where there are large numbers of residents (Coutts, et al, 2011). There is currently little contemporary guidance that planners can use to identify variables to be used for projecting cemetery needs. The study raises important issues such as burial migration and problems estimating cemetery capacity and advocates for the role of planners in being active contributors to forecast for the deceased in light of little available information and policy direction. Creating cemeteries will be one of the most permanent land use decisions, as they are difficult to move and as difficult to plan around. Thus, four factors have been identified by Coutts et al, (2011) for the development of new cemeteries: mortality rates, cremation rates, burial migration, and available land area for burial. In addition, their research suggests that a 30-year horizon should be used for projecting the need for cemetery land. This time horizon allows for an understanding of shifting preferences, demographic changes, and alternative methods to accommodate the deceased.

Despite the recognized importance of death and burial as a social, cultural, and economic phenomenon, planning for cemeteries has received little attention (Basmaijian \& Coutts, 2011; Davies \& 
Bennett, 2016; Kong, 2012; Hussein \& Rugg, 2003; Canofari, 2017). Even though our mortality is the only thing we can count on for any kind of certainty in life, planners and decision makers are not anticipating for it. Planning for the disposal of the dead is a vital public service and it is something that ought to be considered in planning decisions (Capels \& Senville, 1994).

The lack of attention to cemetery needs is not unique to land use policy fields, but also one that has been given little attention in the social sciences and economic fields (Canofari et al., 2017). As a result, planners and decision makers in Toronto and surrounding municipalities lack the regulatory tools, policy frameworks, criteria, and vision to address the long-term needs for its current and future residents. Consequences as a result of this inaction could be significant environmental, social, and economic impacts to vulnerable people within the Greater Golden Horseshoe (GGH) area.

As planners and decision makers will struggle to meet the overall demand for cemetery land, it is important for planners to remain aware of the different religious needs and demands. This would lead to better informed opportunities for improved cemetery development approvals process, policy development, and criteria for the development and expansion of cemeteries.

\subsection{Challenges for Planners in Toronto}

Planners in Toronto are faced with several challenges in meeting the demands and needs of its residents for access for places to live, work, and play. Meeting these needs has shed light into the complex issues of affordability, access, and inequalities across the City. Without taking into account the full cycle of life, planners cannot plan for complete communities. Meaning that planners should be considering not only places for people to live, work, and play, but also final resting places. 
As of 2016, it has been estimated that the remaining cemetery land in Toronto will be exhausted within the next $20-30$ years (City of Toronto, 2016). The lack of cemetery land and increasing demand will not only cause several implications for Torontonians, but for those in surrounding municipalities as well. In March of 2016, York Region released their Cemetery Needs Analysis and Policy Framework which identified challenges, opportunities, and a framework for addressing them. This report estimated that based on current trends and projections for death and growth, York Region may also exhaust their cemetery lands in the coming 30 years due to high demand coming from outside of the region (LEES + Associate, 2016).

Decisions that are made based on existing policies today have long-term implications. Given the sensitive contents found within cemeteries, societies today generally tend to view these spaces as permanent land uses (Larkin, 2011). That is, that cemeteries today are meant to continue to be used for cemeteries in perpetuity and not to be used for another use in the future. Keeping in mind the view of cemeteries as permanent fixtures, determining the establishment for new cemeteries or guidance for the expansion of existing spaces has become ever more important in light of the scarcity of remaining cemetery land and competition for providing for other land uses. In Toronto, where land for development is extremely competitive, existing cemeteries face pressure to balance accommodating for not only the living but also for the dead.

In July of 2016, Councillor Justin J. Di Ciano and Deputy Mayor Denzil Minnan-Wong recommended to the City of Toronto's Planning and Growth Management Committee the development of a Cemetery Needs Analysis and a new Policy Framework to shed light on the remaining burial space capacity in Toronto's cemeteries and to establish a projected need for future cemetery demand. It was also recommended that a set of criteria be established to guide the development or expansion of cemeteries accompanied with a strategy to meet this demand. It was suggested that this needs analysis be conducted 
in consultation with the Province, surrounding municipalities and public consultation that would include faith based groups concerned with this matter. When the motion to conduct a cemetery needs analysis in Toronto went for a vote, it received a minority vote and did not pass. This means that at this point in time, the City of Toronto will not conduct a cemetery needs analysis.

With the remaining cemetery land in Toronto being estimated to be depleted within the next 2030 years, it is important to consider how this issue may present social and economic hardships for people in the future as they may have to seek cemetery services outside of the Greater Toronto Area to accommodate the final wishes of loved ones (City of Toronto, 2016). This issue is further exacerbated when considering the potential social inequality this may cause to some groups in proportion to others. Religious groups that require interment as per their religious practices will experience much more economic hardship as supply-and-demand economic principles demonstrate that the cost for burial will rise as space becomes less available. Thus, as Toronto's religious diversity continues to grow, the organizational makeup of the cemetery industry in Toronto will have a direct impact on how some religious groups will respond to the issue. This is further discussed in Section 4.1.3 The Cost of Cemetery Services in Toronto, of this paper.

\subsection{Choice and Equity for Accommodating the Deceased}

As cemeteries begin to take the role of anchoring immigrant communities (Francis et al, 2000) in Toronto, these cultural landscapes begin to take shape and reflect the social and economic realities of the living. For those with the ability to access existing cemetery land in Toronto, are ones that are able to create lasting memories and character to the cultural heritage landscapes in Toronto. Access to cemetery space is part of a larger discourse of affordability and social and economic dynamics, which are not the scope of this paper, but important to acknowledge. 
Cultural and religious considerations have different degrees of impacting decisions to accommodate the deceased. Each culture and religion will have different views, attitudes, and values towards death, which aids in distinguishing the beliefs and customs that are associated with the different orientations of death (Longoria, 2014). However, relying exclusively on just culture or religious explanations to justify decision-making factors ignores possible economic, political, and social context factors that influence choices (Longoria, 2014). Therefore, it is important to understand the overarching or structural challenges that are also impacting choices for accommodating the deceased.

Discussions around death and how to accommodate the deceased raises questions about factors that influence the methods and locations that are decided upon. Casal et al (2010) conducted research to understand people's decisions and grouped their findings into three main themes: (1) a physical aspect: place identity, mobility, length of residence; (2) a family and social aspect: the choices of parents or spouse; (3) individual aspects such as religion, age, and temporal orientation. Further research is needed to understand how much weight each variable holds in decision making but overall place attachment, place identity, and appropriation were identified as major drivers.

As demographics change, there is the expectation that cemetery providers will respond to these changes. Death competence, as argued by Longoria (2014) is important for making competent policies and management decisions for cemeteries. More importantly, Longoria highlights that cemetery providers must be aware of social equity concerns to ensure that there is fair, just, and equitable access to cemetery services. Recognizing the different needs to meet the cultural or religious practices for accommodating the dead, means the demand for cemetery services is inelastic for some residents and needs to be taken into consideration when exploring the context of income and social inequality 
(Longoria, 2014). This is particularly true for groups that require traditional forms of land burial who will feel the brunt of rising costs as supply for this method of accommodating becomes increasingly scarce.

Klaufus (2016) examined the relationship between cemeteries and spatial justice in Latin American urban cities with a focus on Colombia. Klaufus (2016) presented the argument that goals for sustainable cities that relate to social inequality or depletion of natural resources cannot be accomplished without addressing sustainable land use for cemeteries and other spaces for dead-disposal needs. It was observed that spatial burden tends to be uneven where low-income areas are disproportionately located in close proximity to cemeteries, or where cemeteries for the rich are Eden-like spaces in gated communities and a long travel distance for the urban poor. Overall, the competition for cemeteries results in uneven access which eventually mirrors the spatial segregation of social class within urban centers. This issue is not only restricted to cities in Latin America. A 2010 New York Times Article reported on the shortage of cemetery burial space and the rising grave prices observed that cemetery prices were so expensive in New York that they were just like any other real estate object, with over $\$ 1,000$ USD per square feet. Such rising prices force people who could not afford burial to seek cheaper alternatives such as cremation, which could be in contrast to personal preferences (Santora, 2010).

\subsection{Method}

This MRP is based on: a review of scholarly journal articles; an analysis of land use policies and strategies that are relevant to Toronto area; documents and reports made by the cemetery industry; and semi-structured interviews with senior staff involved in the cemetery industry from both the private and public sector and senior stakeholders from religious institutions. Given the exploratory nature of this 
research, literature review and semi-structured interviews have been determined to be appropriate methods to answer the research questions.

These methods were also utilized in cemetery research studies that looked at the role of cemeteries in contemporary cities in the UK (McCloymont,2015), cultural and religious competency of cemetery operators in Texas (Longoria, 2015) and cemetery management from the private and public sector in Sydney (Davies \& Bennett 2016), which will be described below. Given the limited research in the Toronto context, these research questions tend to tackle new problems where the emphasis of this research is on the discovery of ideas and insights, and understanding the nature of the issue rather than providing conclusive answers (Kothari, 2004).

Toronto has a total of 206 licensed cemeteries with the organizational breakdown of 155 cemeteries associated with religious institutions, 23 not-for-profit, 20 municipal, and 8 that are commercial (Mount Pleasant Group of Cemeteries, 2016). However, the number of cemeteries that are actively providing cemetery services, is much lower. Cemeteries that have remaining cemetery space available for burials are known to be as 'active'. The following are active cemeteries within the GTA, split into organizations divisions 10 religious (Roman Catholic, Anglican, and Jewish), 8 commercial, 5 not-for-profit, and 0 active municipal licensed. This means there are a total of 23 cemeteries currently able to accommodate for the dead, and only 13 of them are considered non-denominational (Mount Pleasant Group of Cemeteries, 2016). 


\section{Selection Process for the three different interview groups:}

\section{Religious Group and Institutions}

The National Household Survey only collects data on religion every 10 years. Based on the most recent data from the 2011 survey, the top religious groups are: Christian, Catholic, Muslim, Hindu, Jewish, Sikh, and Buddhist. For the purpose of this research, the Christian, Catholic, and Jewish groups were not observed for this research as these religious groups currently have cemeteries associated with their religious institutions and have a much longer history in Toronto in comparison to the other religious groups. Thus, religious institutions representing the Islamic, Sikh, Hindu, and Buddhist religious groups and located in Toronto were contacted for interviews.

\section{Cemetery Operators}

In Toronto, cemeteries that have the ability to accommodate a variety of different faiths and cultural needs are run by non-denominational cemetery providers. In Toronto there are 3 different cemetery operators that run and manage the 13 non-denominational cemeteries. For the purpose of this research, management staff from these cemetery operators were contacted for an interview.

\section{Bereavement Authority of Ontario (BAO)}

The BAO administers most of the legislation in the Funeral, Burial, and Cremation Services Act (FBCSA) and supports the regulation and various functions of services in the cemetery industry. The BAO has several committees to support the direction and implementation of the FBCSA, one of which is the Faith Based 
Advisory Committee. This committee provides expert advice to authorities in the cemetery industry whilst providing insight from the various faiths found within the Province. For the purposes of this research, the Chair for the Faith Based Advisory Committee was contacted for an interview.

A total of three interviews were conducted between February and March of 2018. The interviews included an individual in a senior management and operational role for a not-for-profit cemetery and crematoria facility (1 interview); a member of the Faith Based Advisory Committee for the Bereavement Authority of Ontario (FBAC BAO) (1 interview), and senior stakeholder of the Buddhist faith (1 interview). The limited number of interviews reflect the small number of participants in the sector and limited time to conduct extensive primary research. Throughout the paper, quotes and observations from the interviews are provided and are referenced as follows: Int\#1 FBAC BAO; Int\#2 cemetery provider; and \#Int3 religious sector.

Responses from the interviews were analyzed to identify methods and strategies undertaken by the cemetery industry in response to accommodating the various religious needs found in Toronto, and how some religious sectors may be responding to the current cemetery context. In addition, analysis was done to understand how cemeteries in the future are planned, and what emerging trends are surfacing within the cemetery industry and religious sectors that may impact cemetery planning and policy in Toronto.

In order to understand how religious diversity in Toronto is being captured and addressed in the development or expansion of cemeteries in Toronto this research needs to: 1) explore the history of cemeteries in Toronto to gain a historical perspective on the changes and responses from the cemetery industry as a result of shifting demographics; and 2) explore the latest information on data related to 
immigration and religious trends in order to highlight the diverse considerations and needs that ought to be accounted for by the cemetery industry, planners, and decision makers.

\subsection{Limitations}

This study focused its research on private non-denominational cemeteries, but there are options for cemeteries associated with religious institutions that could also be a part of the solution. Due to time constraints there is limited representation from the religious sector to discuss trends or implications of this issue for members of their faith group.

\subsection{Context}

\subsection{Cemetery Lands in Toronto}

This section will examine the historical context of cemeteries in Toronto and look at immigration trends to identify how cemetery industry responds to diversifying ways to accommodate for the deceased.

\subsubsection{Evolution of Cemeteries in Toronto}

The cemetery organizational structure in Toronto is comprised of a mix of religious, not-for-profit, municipal, and commercial cemeteries (Mount Pleasant Group of Cemeteries, 2016), but it was not always this way. Dating back to the expansion of Christianity across Europe and North America, churches began to establish themselves with dedicated churchyard or adjacent lands for accommodating burials for local 
villagers. Until the 19th century, churchyards were able to accommodate for burials regardless of religious affiliation, but were later restricted to members of their congregation (Larkin, 2011).

In 1788, the British established a town on Lake Ontario, known at the time as the Town of York. The area began to develop slowly through the turn of the $19^{\text {th }}$ century as people began to establish themselves. During the early $19^{\text {th }}$ century, burials were along denominational lines, which made existing cemeteries at the time open only to those who belonged to the members of the Roman Catholic Churches and the Church of Scotland (Smart, 2011). This meant that only those that were Anglican and Roman Catholics could be buried in an "authorized" cemetery in the City, while everyone else had to be buried outside of it (Mount Pleasant Group of Cemeteries, 2018). Although family cemetery plots were in existence, the growing population of York made it clear that these family plots would become improbable to continue (Smart, 2011).

One of the responses to this was the emergence of secular cemeteries where there were new opportunities for a wider range of memorials and landscapes that were representative of the architectural and landscaping of the time (Mytum, 2004). The main solution during this time was to establish large cemeteries. In North America, cemeteries were mainly developed through a combination of local governments, private companies, and few provided by secular societies and religious institutions providing cemetery space (Mytum, 2004). In Toronto, the municipal government recognized that there was a lack of facilities to accommodate the need for new multi-faith immigrants. In response, the government passed an Act on January 30, 1826 which allowed land to be purchased and used for a public cemetery that would be open to people regardless of people's social status or religious affiliation (Mount Pleasant Group of Cemeteries, 2006). This eventually led to Toronto's first non-sectarian cemeteries. 
In Toronto, Mount Pleasant Group (MPG) established the first non-sectarian burial grounds in 1826, at the north-west corner of present-day Bloor Street and Yonge Street, known as Potter's Field. This cemetery opened with the mission to accommodate all people regardless of religion (Mount Pleasant Group of Cemeteries, 2018). Around the 1840's there were concerns that Potter's field was going to run out of future burial space. In 1850, the Necropolis Cemetery was opened to alleviate the pressure to accommodate the need for burial space, which also continued the mission to be open to people from all religious backgrounds. An attempt was made to expand the Necropolis by purchasing land south of the cemetery. Local protests stopped the purchase of the land for this use, and was instead transformed into a park. Due to not being able to expand the cemetery, a 200 acre plot was purchased for the development of a new cemetery which is known today as Mount Pleasant Cemetery (Smart, 2011). This trend later continued with the establishment of more cemetery operators who saw the opportunity to provide cemetery services to the growing newcomer population that would not be able to seek services in the Anglican or Catholic Cemeteries.

At the same time, cemeteries dedicated to serving congregations outside of the Anglican and Catholic faiths also began to emerge. The Pape Avenue Cemetery was established in 1849 and is the first Jewish cemetery in the Toronto. Prior to the Pape Avenue Cemetery, Jewish people had to travel to Montreal or Buffalo to be buried in a Jewish Cemetery. The location of the Pape Cemetery was located where Toronto's Jewish community first began to assert itself 170 years ago (Laidlaw, 2008). Toronto's first synagogue was built a few years later after the establishment of the cemetery. For the Jewish community, building a synagogue was seen as less important than establishing a cemetery due to a few factors. Firstly, the Jewish community is still able to practice the faith without an official gathering place (the synagogue), but a consecrated cemetery is a necessity for properly burying the deceased in the Talmudic manner. 
Secondly, the Talmudic requirement for accommodating the deceased must occur within one day of death, which was difficult to do when the closest cemeteries were in Montreal and Buffalo (Laidlaw, 2008).

The trend for establishing cemeteries during the 1800's was by purchasing land in the outskirts of the city boundaries. For economic and health reasons, cemeteries were located and, are often preferred to be, on the periphery of cities (Larkin, 2011). This was the case for several of Toronto's cemeteries that are now found to be engulfed by surrounding urban areas. For instance, Potter's Field was closed down in 1855 to accommodate for the growing city, with the only remaining evidence amongst a series of high rise commercial buildings is a historic plaque at Yonge and Bloor to commemorate the former site.

\subsubsection{Current Cemetery Context in Toronto}

There are both public, private, and religious cemeteries in Toronto. As existing and future immigrants in Toronto begin to seek a place to accommodate the deceased, there are only limited options currently available that can absorb the religious diversity to accommodate the various demands and needs. As discussed below, there are currently only 13 active non-denominational cemeteries and 10 religious cemeteries. Among the available options, the rising cost of the limited supply of cemetery land makes even these options accessible to a limited few. Unless there is an opportunity to create additional supply within all cemetery organizational backgrounds, there will continue to be a limited availability for people of different faiths to access cemetery land in Toronto. Thus, those who are able to be accommodated in Toronto's existing cemeteries will be those who have the financial means to do so, leaving lower-income resident to seek services outside of Toronto.

The current breakdown of the cemetery industry in Toronto is very well illustrated in a report prepared by Mount Pleasant Group of Cemeteries in 2016, Table 1 below compares the different ownership 
categories for the 206 cemeteries in Toronto. The religious category has the highest number of licenses for cemeteries with a total of 155 , but only 10 of them are currently active. The remaining 13 active cemeteries in Toronto fall within the not-for-profit and commercial categories. Out of the 23 active cemeteries in Toronto, 10 are religious and the other 13 are considered to be non-denominational and able to accommodate people of all backgrounds, religions, and cultures.

Table 1. Breakdown of Active and Not-Active Cemetery Organizational Breakdown

\begin{tabular}{|c|c|c|}
\hline Type & Name & Religious Affiliation \\
\hline \multirow{10}{*}{ Religious } & Bathurst Lawn Memorial Park & Jewish \\
\hline & Beth Tzedec Memorial Park Cemetery & Jewish \\
\hline & Dawes Road Cemetery & Jewish \\
\hline & Holy Blossom Cemetery & Jewish \\
\hline & Mount Sinai Cemetery & Jewish \\
\hline & St. James Cemetery \& Crematorium & Anglican \\
\hline & St. John's Norway cemetery \& crematorium & Anglican \\
\hline & St. Margaret's In The Pines Anglican Cemetery & Anglican \\
\hline & Mount Hope Roman Catholic Cemetery & Roman Catholic \\
\hline & St. Michael's Roman Catholic Cemetery & Roman Catholic \\
\hline \multirow{8}{*}{ Commercial } & Forest Lawn Mausoleum \& Crematorium & Non-denominational \\
\hline & Park Lawn Cemetery & Non-denominational \\
\hline & Riverside Cemetery \& Crematorium & Non-denominational \\
\hline & Sanctuary Park Cemetery & Non-denominational \\
\hline & Westminster Cemetery, Mausoleum \& Crematorium & Non-denominational \\
\hline & Glendale Memorial Gardens and Funeral Home & Non-denominational \\
\hline & Highland Memory Gardens & Non-denominational \\
\hline & Resthaven Memorial Gardens & Non-denominational \\
\hline \multirow{2}{*}{ Not For Profit } & Mount Pleasant Cemetery, Funeral \& Cremation Centres & Non-denominational \\
\hline & Pine Hills Cemetery \& Funeral Centre & Non-denominational \\
\hline
\end{tabular}




\begin{tabular}{|c|c|c|}
\hline Prospect Cemetery \& Mausoleum & Non-denominational \\
\cline { 2 - 3 } & Toronto Necropolis \& Crematorium & Non-denominational \\
\cline { 2 - 3 } & York Cemetery \& Funeral Centre & Non-denominational \\
\hline
\end{tabular}

Source: Mount Pleasant Group, 2016

The current breakdown of ownership and affiliation of cemeteries in Toronto tells the history of immigration and preferences of the changing demographics. The breakdown can be seen in the table below:

Table 2: Ownership Breakdown of Active Cemetery Type in Toronto

\begin{tabular}{|c|c|c|}
\hline Type & Name & Religious Affiliation \\
\hline \multirow{10}{*}{ Religious } & Bathurst Lawn Memorial Park & Jewish \\
\hline & Beth Tzedec Memorial Park Cemetery & Jewish \\
\hline & Dawes Road Cemetery & Jewish \\
\hline & Holy Blossom Cemetery & Jewish \\
\hline & Mount Sinai Cemetery & Jewish \\
\hline & St. James Cemetery \& Crematorium & Anglican \\
\hline & St. John's Norway cemetery \& crematorium & Anglican \\
\hline & St. Margaret's In The Pines Anglican Cemetery & Anglican \\
\hline & Mount Hope Roman Catholic Cemetery & Roman Catholic \\
\hline & St. Michael's Roman Catholic Cemetery & Roman Catholic \\
\hline \multirow{8}{*}{ Commercial } & Forest Lawn Mausoleum \& Crematorium & Non-denominational \\
\hline & Park Lawn Cemetery & Non-denominational \\
\hline & Riverside Cemetery \& Crematorium & Non-denominational \\
\hline & Sanctuary Park Cemetery & Non-denominational \\
\hline & Westminster Cemetery, Mausoleum \& Crematorium & Non-denominational \\
\hline & Glendale Memorial Gardens and Funeral Home & Non-denominational \\
\hline & Highland Memory Gardens & Non-denominational \\
\hline & Resthaven Memorial Gardens & Non-denominational \\
\hline
\end{tabular}




\begin{tabular}{|c|c|c|}
\hline \multirow{4}{*}{ Not For Profit } & Mount Pleasant Cemetery, Funeral \& Cremation Centres & Non-denominational \\
\cline { 2 - 3 } & Pine Hills Cemetery \& Funeral Centre & Non-denominational \\
\cline { 2 - 3 } & Prospect Cemetery \& Mausoleum & Non-denominational \\
\cline { 2 - 3 } & Toronto Necropolis \& Crematorium & Non-denominational \\
\cline { 2 - 3 } & York Cemetery \& Funeral Centre & Non-denominational \\
\hline
\end{tabular}

Source: Mount Pleasant Group, 2016

As seen in Table 2, most of the active cemeteries in Toronto are predominantly owned by a religious institution. The major religious groups are Jewish, Anglican, and Roman Catholic. This is reflection of the dominant religious groups that exist in Toronto today. However, the high number of non-denominational cemeteries in Toronto is also telling of the population that may be considered to be part of ethnic, cultural, or religious minority groups.

As discussed in the section above, cemeteries have traditionally been located on the outskirts of the city boundaries for economic and health purposes. Thus, it by no surprise that the cemetery location breakdown of licensed cemeteries reflects this trend. In North York, there are currently 98 cemeteries, 55 of them located in Scarborough, 27 in Etobicoke, followed by 24 in Toronto, and 2 in East York. Thus when considering the development of new cemeteries, or the expansion of existing ones, it is important to take into account the population demographics when making decisions relating to this matter.

The active religious cemeteries are comprised of 5 Jewish, 3 Anglican, and 2 Roman Catholic. As Toronto's population continues to diversify, the change in demographic trends reflected in cemeteries is established based on other religious groups that have yet to make a mark in Toronto's cemetery landscape. This means that people who make up the other major religious population groups in Toronto (Buddhist, Islamic, Sikh, and Hindu practices and rituals) re only able to participate in the active not-for-profit and commercial cemeteries. This matter will be explored in the section below. 


\subsubsection{The Cost of Cemetery Services in Toronto}

As the supply of existing cemetery land becomes scarce and demand continues to increase, the price of cemetery services in Toronto also rises. The non-denominational cemeteries in Toronto are run by private interests which makes their services dependent on market forces and consumer demands. As supply decreases and price increases, cemetery services in Toronto may become unaffordable for many. This section explores the increasing demand for cemetery services and its impact.

According to Toronto's 2016 Census Metropolitan Data, Toronto's population is now estimated to be at $5,928,040$. Those that are 65 years of age or older make up $14.5 \%$ of the total population in Toronto (Statistics Canada, 2017). This means that there are 858,580 people who could be significantly impacted by the limited number of cemetery land available in Toronto in the near future. With the average life expectancy of Canadians being of 81 years of age, the 115,030 residents that are currently 85 years of age or older (Statistics Canada, 2017) will be first major group to experience the brunt of this issue and their families will bear the cost. Considering the 65 years and older age cohort are approaching the average life expectancy, planners and decision makers ought to be examining methods to continue to provide this service for future generations to come.

With a growing and rapidly aging population, the limited amount of existing cemetery land in Toronto has led to the estimation of existing cemetery land to be exhausted within the next three decades (City of Toronto, 2016). Applying the classic supply and demand economic model to the limited supply of cemetery land up against an infinite demand, implies that the price for cemetery services in Toronto will rise and will continue to do so if supply is not increased. 
There is a serious lack of research pertaining to the economics of cemetery plots (Canofri et al, 2017). In the 2017 study conducted by Canofri et al that examined over 10,000 grave prices in the United States, grave and housing prices were both found to be closely related to the price of land. Additionally, there was a statistically significant relationship between grave prices and average housing prices, and they were found to not be significantly related to average personal outcome. One interpretation is that the increased demand for housing is also associated with an increase in the demand for funeral housing which also causes prices for graves to be higher. For the purpose of this MRP, exploring the cost of housing and grave prices is out of scope However, Canofi et al's (2017) research highlights an important layer to be considered when thinking about access and equality for accommodating the deceased.

By applying a simple demand and supply economic model to the availability of cemetery lands available in Toronto, it is evident that the price point for cemetery services in Toronto is a response to high demand and limited supply. The table below demonstrates the costs of interment and cremation services in 5 different cemeteries in different parts of Toronto in comparison to 4 cemetery operators outside of Toronto. For consistency purposes the table contains prices from cemeteries that are all operated by the same provider - Mount Pleasant Group of Cemeteries.

Table 3. Comparison of cemetery services from Mount Pleasant Group of cemeteries ${ }^{1}$ within Toronto and outside of Toronto

\begin{tabular}{|l|l|c|c|}
\multicolumn{1}{|c}{ Cemetery } & Neighbourhood/City & Interment* & Cremation** \\
\hline Mount Pleasant Cemetery & Davisville Village & $\$ 15,875.75$ to $\$ 30,587.70$ & $\$ 650.00$ \\
\hline Pine Hills Cemetery & Scarborough Junction & $\$ 5,597.30$ to $\$ 7,805.00$ & $\$ 650.00$ \\
\hline York Cemetery & Willowdale & $\$ 4,982.35$ to $\$ 6,947.50$ & $\$ 650.00$ \\
\hline Prospect Cemetery & Earlscourt & $\$ 14,150.00$ to $\$ 1,750.00$ & $\$ 650.00$ \\
\hline
\end{tabular}




\begin{tabular}{|l|l|r|c|}
\hline Toronto Necropolis Cemetery & Cabbage Town & $\$ 8,995.00$ & $\$ 650.00$ \\
\hline Elign Mills Cemetery & Richmond Hill & $\$ 2,767.50$ to $\$ 3,587.50$ & $\$ 650.00$ \\
\hline Duffin Meadows Cemetery & Pickering & $\$ 1,998.00$ to $\$ 2,412.40$ & $\$ 650.00$ \\
\hline Thornton Cemetery & Oshawa & $\$ 2,025.00$ to $\$ 2,400.00$ & $\$ 650.00$ \\
\hline Beechwood Cemetery & Vaughn & $\$ 2,403.00$ to $\$ 3,115.00$ & $\$ 650.00$ \\
\hline
\end{tabular}

Table 3. Illustrates the cost of cemetery services for interment and cremation across Toronto and outside of Toronto's jurisdictional boundaries.

${ }^{1}$ Table contains prices from cemeteries operated only by Mount Pleasant Group of Cemeteries, (a not-for-profit cemetery provider) as the organization provides price list for all their cemeteries online. Prices effective as of April 2017.

* Adult grave price, flat marker on ground and does not include memorial costs and cemetery supplies

** Person 10 years of age or older, cost for only cremation service

Based on the information provided in the table above, it is evident that the price of interment and cremation in Toronto is significantly higher than that in the surrounding municipalities. When taking into consideration administration costs and fees, caskets, embalming and costs associated with the ceremony, the price can easily escalate and become even more expensive. Due to limited information on the surrounding municipalities, it is unclear if there is a limited supply of cemetery lands within their jurisdictional boundaries. Thus, for the purpose of this paper it will be assumed that the cemetery demand in municipalities surrounding Toronto are not facing the same supply and demand imbalance.

The high cost of cemetery services in Toronto could continue to rise if the supply of cemetery land remains the same while the demand increases. This could lead to several people unable to make Toronto their final resting place. This could potentially lead to several current immigrants who don't have any existing family plots and future immigrants unable to anchor their communities in Toronto cemeteries. Furthermore, this could potentially lead to certain groups with more representation within a cemetery than others. If cemeteries are meant to be cultural heritage landscapes, there should be an opportunity for everyone to include in these landscapes. 
The high cost of cemetery services in Toronto might act as a trigger for people to seek services outside of Toronto where the cost is significantly less expensive. Thus, if cemetery capacity was increased, it could potentially decrease the cost of cemetery services which would encourage people to find their final resting place in Toronto. This could also derail the potential cemetery sprawl which can place pressure on environmental protected areas and valuable agricultural lands. This issue is explored in more detail Section

\section{0 .}

\subsection{Religion \& Immigration Trends}

\subsubsection{The Diversifying Religious Demographics in Toronto}

Toronto is already known as being as one of the world's most diverse cities and most likely will continue to be this way in the future. As the newcomer population in Toronto is projected to rise, so will the mosaic of cultural and religious practices that come with them. As new communities start to form and begin to establish themselves, looking at immigration population trends helps paint a picture of what potential changes might occur in the cemetery industry or within religious communities.

For the past 15 years, Canada has maintained the trend of being the fastest-growing country among the industrialized nations. With a commitment to high levels of immigration from the Canadian Federal government, it has been considered the main reason for Canada's continued steady population growth (Friesen \& Cardoso, 2017). Because of the high flow of immigration, it has been estimated that approximately two-thirds of Canada's population increase is due to immigration. According to the Canada Census 2016, the yearly intake of immigrants is over 250,000 per year. In 2017 alone, the government projected that immigration would be between 280,000 and 320,000 , which is considered one of the biggest waves of immigration in Canada in a long time (Friesen \& Cardoso, 2017). 
With the expectation that Canada will continue to remain open to newcomers, it's possible that Canada could reach a point at which migration could become one of the main drivers of growth as natural increase in the population continues to decline and immigration to grow. With these trends in mind, it has been projected that by 2056 , migration could be the sole driver influencing population growth (Friesen \& Cardoso, 2017). The graph below demonstrates the average population growth rate in Canada by natural and migratory increases.

Graph 1: Population Growth Rate Projected in Canada

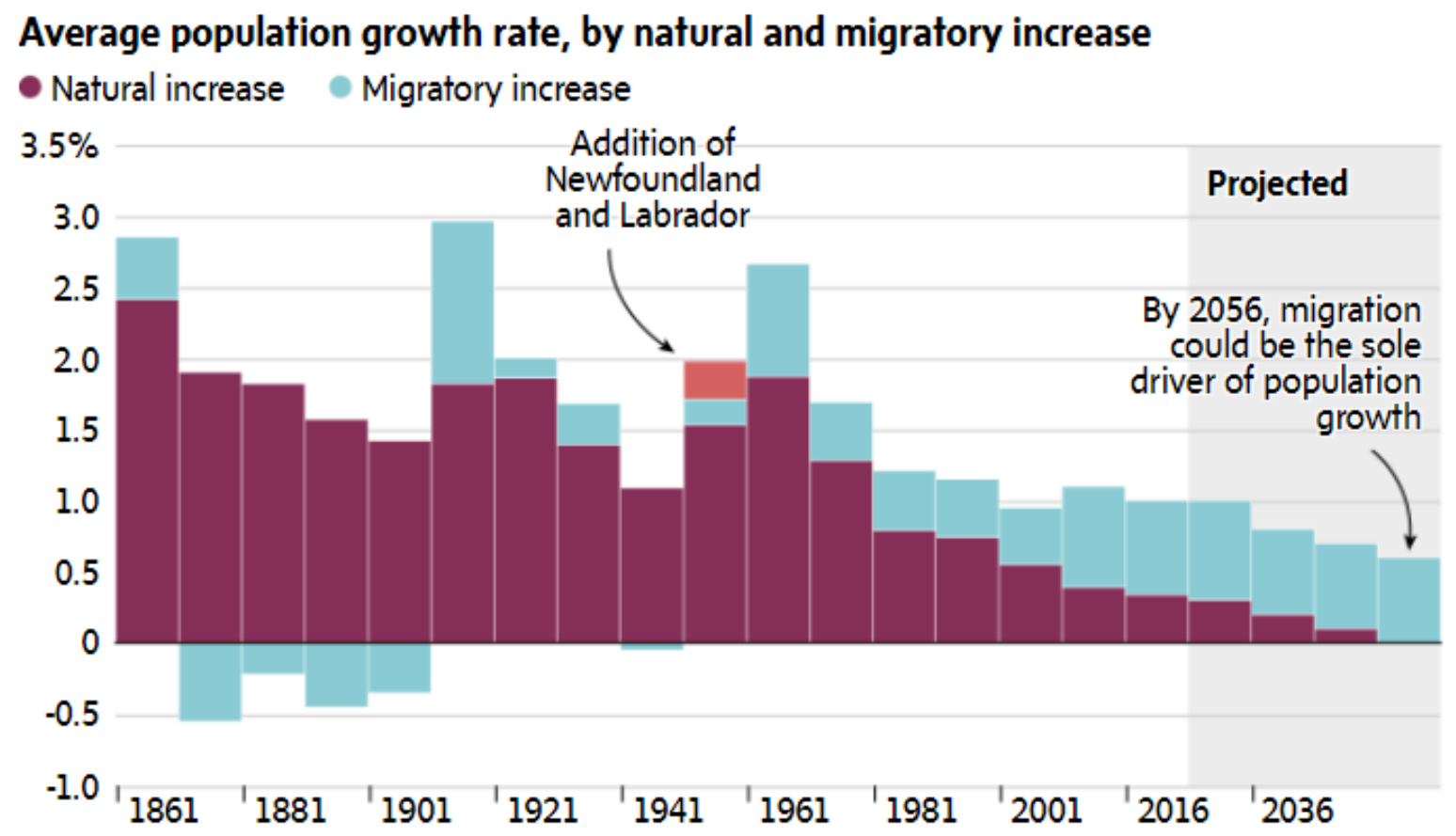

Source: Friesen \& Cardoso, 2017

With Canada's rich cultural and religious diversity, Canada has become a multicultural and multi faith society that is committed to maintaining the rich cultural heritage and practices of minority groups. Agrawal and Hathiyani (2007) stress that as Canada becomes increasingly multicultural it is important to recognize the various customs that different global communities. This can also be expanded in understanding the different customs for accommodating the deceased. While views of death and religion 
are intimately tied, it follows that religion and accommodation for the deceased are similarly linked. However, as argued by Kymlicka, discussion of religion in discourses on multiculturalism is not prominent and is in fact considered one of the most controversial topics within multiculturalism (2010). Therefore, it is important to not only consider discussions of examining immigration trends from a cultural diversity perspective, but also from a multi-faith view as well.

Census data on religion is only collected by Statistics Canada every 10 years. Currently, the most recent information available for religion is based on the 2011 National Household Survey. This data is collected on a voluntary basis which raises questions around accuracy and true religious diversity in Toronto. With the latest waves of immigration experienced in Toronto, it also questions the accuracy of religious diversity in Toronto. The Graph below illustrates the growth of some of the major groups over the course of 20 years.

The data shows that the Christian faith makes up the largest religious group in Toronto. The other religious affiliations that also make a large part of Toronto's population are the Buddhist, Hindu, Jewish, Muslim, and Sikh groups. However, more notorious is the large number of the population that identifies themselves as Non-Religious. In fact, based on the latest 2011 Religion Census Data statistics, the NonReligious Affiliation group is comprised of $1,165,015$ people, which is more than the combined total all of the other religions, excluding the Christian group combined, accounting for 1,136,545 of the population. Therefore, in terms of understanding how religion is impacting the cemetery industry, based on these findings, it is important to also consider how people who do not consider themselves to be part of a religious affiliation may be impacting the cemetery industry. 


\title{
4.3 Changing Consumer Tastes and Preferences Impacting the Cemetery Industry
}

The style and characteristics of modern non-denominational cemeteries today are able to provide a variety of options to prospective clients in order to meet the range of needs for burial/interment rituals and respond to demographics where the cemeteries are located (Larkin, 2011). Typically, these cemeteries are characterized as having park-like features, hence the use of these spaces as important green/open spaces within the urban fabric. Special features within modern cemeteries often include as described by Larkin (2011) are:

\author{
"Burial gardens with in-ground memorials and upright granite \\ monuments, tranquil cremation gardens, and walkways, above ground \\ columbarium niches for cremated human remains, mausoleums, crypts, \\ and personalized memorial features such as benches, trees, and \\ landscape elements."
}

Larkin (2011), pp. 23

The demographic changes experienced in Toronto have not only created the need for the development of non-denominational cemeteries, but also these cemetery providers have had to become sensitive to the growing needs from Toronto's changing population. One of the ways that this happens is by cemetery staff becoming culturally competent and by religious or cultural groups clustering in certain areas of the cemetery. On the other hand it has been observed that religious groups have been responding by establishing new cemeteries outside of Toronto's official boundaries. The former will be explored in this section, and the former in later sections. 
In the context of having staff become more culturally and religiously competent, it's important that training and its application does not reinforce cultural stereotypes. Longoria (2014) studied how the concept of cultural competence is an emerging theme in death studies and could be applied to policies related to cemetery management. It has been argued by Longoria (2014) that cultural practices influence the future demand for cemetery services and that cemetery managers should be taking into account changing consumer tastes and preferences.

\subsection{Planning Policy Context}

\subsection{Policy Planning Framework}

Planning for the adequate provision of cemetery land is a matter of having an appropriate policy framework, long-term vision, strategic plan, and guiding principles. In essence, this debate centers on conserving existing cemetery land from development pressures and ensuring that there is sufficient cemetery land to meet future cemetery needs. When these two matters are not addressed, Hussein and Rugg (2003) have identified in the case of the UK that this can result in lack of burial space, uneven provision of services, inequities in costs. Ultimately, this has been argued by Hussein and Rugg (2003) as strategic policy failure. This strategic failure is found to relate to larger policy planning weakness. Being able to accommodate for the dead in Toronto will need to be facilitated by having the right planning tools and policy framework. This section will focus on the cemetery planning policy framework that currently exists as it relates to Toronto's context. 
In Ontario, the Funeral, Burial and Cremation Services Act (FBCSA) regulates the way cemeteries and funeral establishments are created and operated. The Ministry of Government and Consumer Services is responsible for providing the legislation, regulations, and specific sections within the FBCSA and also provides insight to the Bereavement Authority of Ontario (BAO) (Ontario, 2017). The BAO administers most of the legislation in the FBCSA on behalf of the Ministry of Government and Consumer Services and is responsible for regulating and supporting various functions and services within the cemetery industry such as: "crematorium operators, transfer service operators, funeral directors, funeral pre-planners, transfer services sales representatives, cemetery sales representatives, and crematorium sales representatives across Ontario" (BAO, 2018). With the guidance of FBCSA and the BAO, the cemetery industry has the necessary support in order to manage their everyday responsibilities for a functioning industry. However, planners and decision makers currently have limited policy guidance and tools in order to ensure that this essential social service continues to be accessible for all Toronto residents.

Below is brief overview and discussion of the land use planning policies that are relevant to the conservation, development and management of cemeteries in Toronto.

\subsubsection{The Planning Act}

In Ontario, the Planning Act sets out the guiding rules for land use planning which describes how land uses will be controlled and who may control them. The Planning Act is a way to bring provincial interests to local municipalities and gives local representative authorities the ability to prepare official plans and develop zoning by-laws that will guide future development and protection of natural resources. Under the Planning Act, the Minister of Municipal Affairs and Housing may issue statements on land use matters that are of provincial interest. The Provincial Policy Statement (PPS) of 2014 applies to the entire province 
of Ontario and it sets out policies that align with the vision for how to manage our resources and building strong resilient communities for the long term. In Ontario, the Province has developed a variety of plans that have been created with the intention of promoting intensification of urban areas to accommodate future growth. This places emphasis on the protection of rural and agricultural lands that are meant to be protected from new development.

With existing cemetery land in Toronto rapidly depleting, and extremely high land prices there is little incentive to purchase land in Toronto for new cemetery development. Resulting in new cemetery development being located in the fringes of cities, where land is more economically feasible. Locating large cemeteries at the periphery of cities is contrary to the mantra of provincial planning plans which encourage intensification of existing urban areas. Therefore there is a need to not only provide provincial guidance for municipalities to guide the development of new cemeteries and expansion for existing ones.

\subsubsection{Ontario Heritage Act}

The Ontario Heritage Act was enacted in 1975 to allow municipalities and the provincial government to identify properties or districts that have cultural heritage value or interest and give them heritage designation status. Regulation 9/06 of the Ontario Heritage Act outlines a list of criteria for which a property of interest can be evaluated to determine its heritage properties as a way to protect the property for its cultural and heritage value to our communities. This Act, according to Section 27 requires that municipalities keep and maintain a registrar of properties that have been identified as being of cultural heritage value or interest.

Important heritage structures can come in many different forms, such as landscapes, buildings, districts, and even engineering structures. Cemeteries are considered to be, according to this Act, part of 
the cultural heritage landscapes definition. Cemeteries fit into this category because they have a solid grouping of structures such as the grave stones, mausoleums, and columbarium among a vast open space, and most importantly holds a unique yet shared meaning for most people that visit the site, despite the macabre element of use.

The City of Toronto places a lot of importance on heritage conservation as a priority in the development of the City. This is expressed in the City of Toronto's Official Plan which stresses the policy of protecting and enhancing properties and districts within its political boundaries (City of Toronto, 2017). Utilizing the Toronto's Heritage Registrar's Property tool, there are several (approximately 20) cemeteries that have been designated under Part IV or Part V (Heritage Conservation District designation or District Designation respectively) of the Ontario Heritage Act

\subsubsection{Provincial Policy Statement}

The PPS is considered to be a complimentary policy document that communicates the interests of the Province as it relates to land use planning and development. The PPS provides policies pertaining to matters related to housing, employment areas, public spaces, parks and open spaces. In Larkin's (2011) policy scan for cemetery development and management for Ontario Municipalities, it was stated that the PPS 2005 "does not identify the provision of opportunities for the development of new cemeteries as a key component of community development."(pp. 53). Instead, the PPS 2005 only refers to cemeteries as being part of "Cultural Heritage Landscapes". In the PPS 2014, cemeteries were not only recognized as significant cultural heritage landscapes, they were also recognized as an important element for healthy and sustainable communities. 
In section 1.1 Managing and Directing Land use to Achieve Efficient and Resilient Development and Land Use Patterns of the 2014 PPS, cemeteries have been identified as being important elements for a healthy, livable and safe community. Section 1.1.1 (b) states that:

\author{
"Accommodating an appropriate range and mix of residential (including \\ second units, affordable housing and housing for older persons), \\ employment (including industrial and commercial), institutional (including \\ places of worship, cemeteries and long-term care homes), recreation, park \\ and open space, and other uses to meet long-term needs;"
}

This recognition emphasizes that cemeteries are important institutional land uses that ought to be considered in land use decisions. However, beyond this recognition there is little emphasis that guides regional or municipal planners on how to balance this need among other important land uses or any specific targets that need to be considered.

\title{
5.1.4 Growth Plan for Greater Golden Horseshoe
}

The Growth Plan for the Greater Golden Horseshoe (2017) is a long-term plan that works in conjunction with other Provincial Plans such as the Greenbelt Plan, the Oak Ridges Moraine Conservation Plan, and the Niagara Escarpment Plan as a way to manage growth, curb development sprawl, protect the natural environment and ecological functions, in order to support the development of complete communities. In this plan, cemetery land is permitted in Designated Greenfield Areas and considered to be part of important cultural heritage landscape (Ontario Ministry of Municipal Affairs and Housing, 2017) 


\subsubsection{Greenbelt Plan}

The Greenbelt is a protected area of green space that contains many of Canada's most important ecological and hydrologically significant natural environments and scenic landscapes. It is also home to Canada's most important and productive farmland to support a strong agricultural productivity. This plan identifies where urbanization should occur as a way to ensure that there is sufficient protection to the agricultural land base and the ecological features and functions occurring on the landscape. In the Greenbelt Plan 2017, there is some provincial guidance on where cemetery lands could be located.

Policy 3.1.4 Rural Land Policies, outlines the permitted use for lands falling within rural lands of the Protected Countryside. In Section 3.1.4.1 of this policy it states the following: "Rural lands support and provide the primary locations for a range of recreational, tourism, institutional (including cemetery) and resource-based commercial/ industrial uses." (Ontario, Ministry of Municipal Affairs and Housing, 2017). Furthermore, in Section 4.1 "Non-Agricultural Uses" provides further guidance on how rural lands can be used. It states "The rural lands of the Protected Countryside are intended to continue to accommodate a range of commercial, industrial and institutional (including cemetery) uses serving the rural resource and agricultural sectors." (Ontario, Ministry of Municipal Affairs and Housing, June, 2017). In addition, similar to the Growth Plan designation, cemeteries are also considered an important part of Ontario's cultural heritage landscape.

With this plan also directing growth into already built up areas and where protection of valuable agricultural and green areas is a provincial priority, it is important to balance the needs of not only planning for the living but also for the dead within existing built areas in order to meet the intentions of this plan. 


\subsection{City of Toronto Official Plan}

The City of Toronto's Official Plan guides how the City will evolve and reach its full potential in areas such as transit, land use, development, and the environment (City of Toronto, 2018). During the development of Official Plans, they are aligned with the Provincial Policy Statements issued under the Planning Act and must not conflict with any other provincial plans (Ontario, Ministry of Municipal Affairs and Housing, 2015). This means that the land use policies in the Provincial Policy Statement become an essential part of the land use planning decision making process at the municipal level.

In Section 4.3 "Parks and Open Spaces Area" of the Toronto Official Plan 2015, cemeteries are identified as sites that are a part of Toronto's green open space network. In these land use designations, development is generally prohibited with a few exceptions, including the development of cemetery facilities on these sites. There are no policies that speak to the development of cemeteries, but there is one about parks development in general.

The policy scan discussed above illustrates that there is limited consideration for cemetery planning, policies, and direction for all levels of government. Although Cemeteries hold significant cultural heritage value for communities across Ontario, this limited view of cemeteries creates a narrow discourse and a possibility for municipalities to ensure there is sufficient space to accommodate the deceased. The recognition that cemeteries are an important institutional use in the PPS 2014 is not sufficient guidance for municipal or regional planners to make informed decisions or targets for cemetery development.

Toronto designates cemeteries as open spaces and parks, which is not consistent with the PPS 2014 which identifies cemeteries as institutional uses. With this mismatch, it is difficult for Toronto City planners and councils to fully address this need with policies that are not consistent nor detailed enough to allow 
for informed decisions for the development or expansion of cemeteries in Toronto. If Toronto is to develop new cemetery lands in institutional land use designated areas, as the PPS outlines, considerations for appropriate policies and zoning will be required to allow this use to happen in Toronto's institutional areas.

The following section will tie these policies into the interview data analysis to highlight the challenges and opportunities that planners and the cemetery industry currently face.

\subsection{Findings \& Implications}

Cemeteries offer a variety of social and environmental benefits to our societal fabric. Regardless of the different views, specific uses, and functions, cemeteries first and foremost are meant to accommodate the deceased. Although death is the only certain thing we can count on in life, planners aren't anticipating for this. Cemeteries in Toronto are anticipated to be exhausted in the next 30 years or less which will have significant ramifications if not addressed. Based on the literature review, policy analysis, and interviews, several implications related to this issue emerged.

There are five major findings that emerged from this research:

1. There is very limited provincial policy guidance to support the development and expansion of existing cemeteries;

2. Municipalities surrounding Toronto, within the GGH area will be the first to experience the brunt of people seeking more affordable land. This will cause cemetery land in those municipalities to also reach the limit of their capacity if additional supply and methods for accommodating the dead are not offered. 
3. Religions that require burial as the method to dispose of the deceased will experience a disproportional burden due to the lack of supply and rising costs. These groups are also more likely to become self-organized, pool resources, and acquire land for cemetery purposes to accommodate their religious needs.

4. People that have identified as non-religious have been impacting the cemetery industry by influencing the market by requesting different methods to accommodate the dead.

Cemeteries play an important role in anchoring immigrant communities and should be part of the conservation around inclusive communities, place making, and identify within the rising multicultural planning paradigm.

\subsection{Limited Provincial Policy Guidance for Cemetery Development}

"Land is the issue, land is definitely the issue. And another issue to layer on top of that are zoning by-laws. Once upon a time cemeteries would typically use agricultural land. The by-laws have changed. Cemeteries are not allowed to use agricultural lands. They cannot afford commercial land values, it's just too expensive. So the cemetery operators are in a bit of a box there. The municipalities are kind of waking up to that too."

Int\#1 FBAC BAO 
Land use planning decisions in Toronto are made on the basis of a top-down policy framework guided by the Province of Ontario. The Province has made its intentions to protect agricultural and natural areas clear in several plans which municipalities are bound to adhere to. This is seen in the Growth Plan and the Greenbelt Plan, where growth is directed towards already built up areas. Provincial plans also provide guidance for matters related to housing, employment areas, public spaces, heritage, parks, and open spaces. Toronto's land use policies are required to conform to the vision that the Province has established. Thus, if land use policies and plans at the Provincial level have limited considerations for the provisions of cemeteries, it is not surprising that Toronto also has limited considerations.

For the most part, Provincial policy documents identify cemeteries as cultural heritage landscapes as outlined above. Cemeteries hold important cultural heritage significance, but this categorization can be limiting and counterproductive in realizing the need for these spaces for the future. Identifying cemeteries as primarily cultural heritage landscapes instead of places that should be considered along with other land use planning considerations, portrays this land uses as static, non-developable, and a use of the past. With this perspective alone, expansion or intensification of existing cemeteries seems impossible as it may compromise their heritage attributes or characteristics. Although not all cemeteries in Toronto are designated as cemeteries, there are no guidelines that speak to ways to increase supply on these sites if needed.

The Greenbelt Plan 2017 may be the only Provincial policy document that identifies cemeteries as appropriate use for the development in rural lands in the Protected Countryside. This allows the potential provision of cemetery development outside of the city core. This can provide an opportunity to developing cemetery lands in more financially- feasible locations. This Plan, like the other Provincial planning documents, speak to the need to guide growth in areas that are already build up. Keeping this development 
mantra in mind, cemeteries should also be considered in discussions of intensification and density. In an era where land is scarce, natural resources are diminishing, and in light of increasingly aging population, alternative methods to the garden like cemetery need to explore.

"There is no question to me that the Provincial Policy Statement has to incorporate and recognize the need for cemeteries in all municipalities, not just the GTA, but its most acutely felt right now in the GTA. When Official Plans are being assembled by municipalities, they should be mandated to provide a certain percentage of or setting aside a certain percentage of land that they would accept applications to rezone as cemeteries. "

Interview \#1 FBAC BAO

In the interview with the representative from the FBAC for the BAO it was expressed that the Province plays a major role in the ensuring that municipalities are providing the necessary land to meet these demands. With the current policy planning framework and guidelines from the Province, the City of Toronto has identified cemeteries as part of the Toronto's connected green network. Within this view, cemeteries are viewed as parks and open spaces. In a dense and highly populated city such as Toronto, cemeteries offer a green oasis in the city. However, this designation fails to view the essential public service that cemeteries are meant to provide.

Hussein and Rugg (2003) argue that the issues related to the adequate provision of cemetery services in London is due to strategic policy failure. One of the factors identified as underpinning the strategic failure surrounds the discussions around the delivery of cemetery needs being driven by local 
government control. Although it has been recognized that cemetery needs is most appropriately managed at the local level, there is also a need for an overarching agency that is responsible for the overarching strategic responsibilities to ensure long-term availability of this service within each municipality. In the case of Toronto, it is the responsibility of the City to ensure that spaces for cemetery services remain in reach for its residents. However, as demonstrated above, Toronto's city decision makers may require the political push from the Province. Just as the province provides guidance on matters related to the living, considerations should also be given to those that have passed and their families.

\subsection{Interjurisdictional Death Sprawl}

The mantra of development and several provincial plans is to maximize land that is situated in already-built areas. With housing developments sprawling outside urban areas, it places a lot of pressure on agricultural and rural lands. The same is true with the continued focus on expanding cemetery development into these areas. With limited land within urban areas to be utilized as cemeteries, and more economically feasible sites outside of the urban areas, cemeteries themselves will be spreading outside of urban areas, going against the mantra development. With this it can be said that cemeteries development can be considered death sprawls - sprawl of landscapes of death.

In 2015, York Region underwent a cemetery needs analysis and policy framework exercise. The need for a cemetery land analysis was raised as an issue in 2012 in response to an OMB appeal as part of the Municipal Comprehensive Review process to update the Official Plan in 2014. The report identified an urgent need for land use policies that would lead to sufficient cemetery lands for future generations of residents in York Region and surrounding communities. Currently, cemetery services sought in York Region by non-residents is $33 \%$ of annual interments. If this rate does not change, combined with the current rate of resident usage, the current inventory of cemetery land will be expected to last for another 30 years. If 
the usage of cemetery inventory is utilized by non-residents, it is expected that the remaining inventory will be less than 25 years. In the report it has been recognized that Toronto, as a major City being close proximity to several cities within York Region, that they will experience the greatest pressure from nonresidents utilizing their cemeteries in the coming years (LEES + Associates, 2016).

The cemetery needs analysis conducted for York Region highlights the need towards having a provincially-led initiative to accommodate the deceased. As access to cemetery space within Toronto becomes more expensive and inaccessible, especially for those religious traditions requiring traditional burial, Toronto may not be able to be the final resting place. With people having the freedom to purchase cemetery services outside of their own city, and easier access to mobility choices, municipalities surrounding Toronto will be the first to experience this trend. This is because as discussed above, the prices outside of Toronto are significantly cheaper. Not only does this cause stress for family members and friends alike to travel long distances to visit their loved ones, it also places additional burden for other municipalities to accommodate the deceased for non-residents.

\subsection{Social and Economic Inequalities}

The combination of limited cemetery land supply, increasing demand, and rising prices for cemetery services has implications for who has access to cemetery services in Toronto and who can choose Toronto as their final resting place. This is especially true for religious traditions and practices that require traditional burial methods to accommodate the deceased. These groups are looking at exponentially higher costs than those people with more flexibility and options for accommodating the deceased. In a city such as Toronto, where diversity is celebrated, our cultural heritage landscapes should also reflect this diversity. Whether this means having access to practice traditional religious practices within a non-denominational 
cemetery or members of faith groups being able to develop cemeteries according to their own faith. As planners are not able to plan for specific users, and only the use of a land, it has created a complex challenge to meet the demands of different religious faith groups.

In an interview with The Guardian (Naomi de Sousa, Jan 2015), Dr. Julie Rugg from the University of York's Cemetery Research Group speaks to a not-too-distant future where private cemeteries in the outskirts of cities can provide short-term grave rentals where burials begin to look more like a sub-sector of the property market. In light of this potential direction, Rugg believes that location and long tenure for cemeteries would become the privilege of urban elite, while being inaccessible to many and potentially separating families and relocate to less desirable locations as long as someone is able to continue paying rent. The potential for this scenario in Toronto raises several questions around equity, access, and disproportional experience of burden among some groups versus others.

In Ontario, and like many other places around the world, the cemetery business is the only type of business that sells something once and then takes care of it in perpetuity. Without cemetery operators being able to provide grave reuse, remaining cemetery land comes at a premium price. This was expressed in an interview with a not-for-profit cemetery provider that expressed the need to stay competitive in the market in order to be able to sustain the provision of this service for long-term:

"We need to be fair and competitive with what else is out there and ensure that we are providing the types of services that people need and want but it's at a fair market value. Because we have to sustain ourselves forever."

Interview \#2 cemetery provider

As identified in the literature review, cultural competency is not sufficient to address the repercussions that arise from social and economic inequalities. Limited supply of cemetery land and an 
increasing demand for the service coupled with the lack of policies to ensure long-term supply raises concerns about issues of access and affordability. This is especially true for some religious traditions such as those practicing Islam. Muslims are required to be buried as part of their religious practices for accommodating the deceased. This pushes families to seek services outside of the city or to pay substantially more money for interment rights in the City versus at the outskirts. Although the impact is felt more acutely for those that require interment methods, this trend is also experienced by members of other faith groups that traditionally opt for cremation methods which is normally cheaper than interment. In an interview, a representative from a Buddhist temple observed the following from their involvement in an annual cemetery visit to commemorate the dead:

\footnotetext{
"Now I see more and more families going out of Toronto. I know that are families that have large plots to serve a certain family. More and more I know because I'm involved with the cemetery visitation and families are going out of the GTA area because of space and probably because of [cemetery] costs. Within the City limits it's probably more expensive."
}

Interview \#3 religious sector

As rates of immigration and religious diversity continues to rise, communities from particular religions or cultures may be interested in addressing this issue themselves. One way that this is addressed is a representative from a religious group approaching a cemetery provider and purchasing the permits for a section of the cemetery or attempting to establish a religious cemetery to specifically accommodate the needs of their religious group. The latter option has been occurring within the GTA and other provinces in Canada which have demonstrated an entirely different set of issues that not only highlight the limited policy 
planning framework to support cemetery development, but also embedded structural inequalities that religious minority groups experience.

"There is a basic right to express one's faith and yes that sometimes makes life complicated for municipalities and planners that would prefer to have an industrial park. But in a multicultural and multi-religious society, our commitment to diversity means that we should accommodate those groups where that interest is translatable to establish a cemetery for their members or for their denomination."

Interview \#1 FBAC BAO

In addition, the establishment of religious cemetery institutions raises tensions between those in favour of religious accommodation and those that are proponents of secularism. For instance, in a small town outside of Quebec City, a proposal for a zoning amendment to allow the creation of a Muslim cemetery was voted down in July 2017. Those against the zoning were in favour of inter-denominational cemetery faiths, something that does not meet the religious needs of religious groups (Copper, July 17, 2017). The first Muslim cemetery was approved in the Greater Toronto Area in 2012. This has been a collaboration between different Muslim communities and will be the first to manage services according to Muslim customs. The cemetery is expected to hold 40,000 graves to accommodate people in adherence to Islamic traditions.

Although there has been some success within the Muslim community to establish a religiously accommodating cemetery, not all religious traditions are able to accomplish this nor necessarily require it. Catholic groups have been present for over 400 years, which represents an institutional system of hierarchy 
that people must navigate in order to efficiently go through the planning process. In the interview with $\mathrm{BAO}$, institutional capacity and professional staff were identified as important resources to go through the planning process.

"... a lot of commenting agencies all of them are given the opportunity comment on the rezoning of OPA applications to establish a cemetery and it costs, aside from the land acquisition cost, the cost to provide all this information under the planning act is onerous and is completely compromising the ability of religious groups to build cemeteries for their members."

Interview \#1 FBCA BAO

Other religious groups such as those practicing Buddhism may not necessarily require their own religious cemetery. In the interview with their representative, the interviewee stated the following:

In Buddhism one of the things that we say always is that we emphasize impermanence. That all things change and that we must change. We must accept the change so that as much as we would want our family members would want to be buried at Mount Pleasant, if it's not possible, then we accept that and make the change.

Interview \#3 Religious Sector

For the other religious groups focused in this research - Hindus and Sikhs - cremation is the main method to accommodate the deceased. More importantly, scattering the remains over water is an important component for commemorating their loved ones. In 2012 scattering cremated remains on Crown land, including land covered water is permitted as long as it doesn't have signs or postings that 
prohibit scattering (Ontario, 2017). Having this flexibility may require less of a need to have dedicated spaces dedicated to urns, and dedicated scattering areas. It may however, become a shift in crematoriums that provided religiously specific customs for the cremation process.

\subsection{Spirituality Vs. Religion Influence on Cemetery Industry}

"While formal religion may be declining, spirituality still exists and all these individuals that are claiming no religious affiliation, many of them still hold onto spiritual beliefs. And what that means in terms of the end delivery and the service, funeral services themselves are taken on a completely different look, feel, and structure. Previously they used to be extremely rigid. Not anymore, it's what does the family want, what's important to them, what makes it meaningful to them."

Interview \#2 Cemetery provider

This research aimed at understanding how religious diversity was impacting the cemetery services provided in non-denominational cemeteries. An unexpected finding from this research was the actual impact and driving force the Non-Religious group has on the industry. In the latest National Household Survey, those that identify as Non-Religious make up an even larger component of the population compared to the combined numbers of Muslim, Jewish, Sikh, and Hindu practicing people. In the quote above, those that are identified as spiritual are described as people who have removed themselves from religious traditions. In particular, it was identified that the Non-Religious group may be people that come 
from the Catholic traditions (Interview \#2 cemetery provider). But as seen in the following quote, it appears that non-denominational cemeteries will rather focus on a blend of a growing religiously-tied group whilst also providing alternative methods for the growing changes and needs from the most spiritual individuals:

"I don't see the Muslims or Hindus communities really changing their practices. At least not yet. Maybe once they become more westernized they might. But then I even wonder, what does the concept of westernism look like because, if you look at the dramatic change in the GTA, these groups are coming into the GTA and their influences are becoming what's normal as opposed to what the western normal is. So there is blend of cultures happening."

Interview \#2 Cemetery Provider

\subsection{Anchoring immigrant communities}

As immigration is expected to become the City's main source of population growth, place-based attachment and anchoring of communities, can be facilitated through cemetery development. Cemeteries are places where people set roots, and for first-generation Canadians this has a significant impact in centering and rooting communities to an area. This was seen in the evolution of cemeteries for the Jewish population in Toronto. This trend will likely continue as more and more new immigrants enter into Canada and make Toronto their home. 
Thus, it could be argued that the first wave of first generation Canadians, in Toronto will have a lasting impact for second generation, but also the next waves of immigration. Furthermore, as cemeteries become places where immigrants begin to anchor roots, it is important to understand the implications of those who are unable to make Toronto a final resting place for their loved ones. As these spaces are considered to be places that hold significant shared cultural heritage value, the relevancy of these spaces for the future depends on what happens in the present and near future.

With different faith groups aiming to meet the needs of their congregation, this may result in the cemetery operators becoming more flexible and further adapting to meet the needs of the community, or the shift could be made through the community group. As more members of a specific group are able to organize their resources and dedicate the time to acquire land for a religious based cemetery, there may be an emergence of new faith-based specific cemeteries or sites.

\subsection{Recommendations}

\subsection{Provincial Guidance and Regional Coordination}

Opposition to new cemetery development and expansion of existing cemeteries, combined with lower land value in the periphery of cities have resulted in a pattern of cemetery development that persists in many Western countries (Bennett \& Davies, 2015). Given that the Greater Golden Horseshoe is one of the fastest-growing regions in North America, one must be cautious of this cemetery development pattern in the periphery of major urban areas as it could potentially lead to its own sprawl which is not in the designated form of residential development. 
The Provincial Growth Plan for the Greater Golden Horseshoe (GGH) provides a vision intent on managing growth in the region and keen on economic prosperity and environmental protection. This vision would inform several planning-related decisions such as land-use planning, urban development, housing, local services, transportation, environmental infrastructure and economic development. Since plans and policies are only as successful as their implementation, a significant effort is needed from government and other parties to fulfill the vision (Ontario, 2004). Capels and Senville (1994) argue that just as we plan for roadway networks, community amenities, parks and schools, cemeteries should be given just as much attention. This argument stresses the significance of including cemeteries into the planning process that cities, towns, and regions take for other types of infrastructure, community, and services.

Modern cemetery developers seek properties that are approximately 40 hectares and above ( 100 acres + ) in size (Larkin, 2011). For economic reasons these sites are often sought out on the periphery of cities, and even if a suitable parcel of land was available in an urban area for development, the use for cemetery would not be top priority (Larkin, 2011). Stressing the importance of creating more supply on existing cemetery lands. Due to limited guidance from the Province, municipalities in the GGH have little to no incentives to plan for cemetery needs within their jurisdictional boundaries.

Thus, municipalities not only within the GGH but most of Ontario are currently unable to manage the incoming demand and needs for this vital public service. Without careful planning, this issue may potentially creep into valuable environmental and agricultural lands which is contrary to the vision and intention of the Growth Plan. As intensification and densification are the mandates of the Growth Plan, planners and governments find themselves in a difficult place to make decisions on a use that is generally considered to be permanent. Although the context for cemetery planning within the GGH is full of 
complexity, with careful planning, cemeteries have the potential to satisfy competing demands for space, environmental preservation, and economic activity (Basmajian \& Coutts, 2010).

Like other planning problems, with spillover effects, Basmajian and Coutts argue that planners can work to encourage regional cooperation around burial (2010). This can be done through experimenting with techniques to encourage local governments to work together to create regional burial plans that would allow for a more equitable distribution of cost and benefit (Basmajian \& Coutts, 2010).

\subsection{Regional Strategic Plan for the GGH Area}

As Toronto's cemeteries reach their limit, it is expected that people will travel beyond their City limits to seek more affordable services. This means that surrounding municipalities will be the first to feel the pressure from Toronto residents seeking services that they are not able to afford in Toronto. This could also mean that the development of new religiously accommodating cemeteries could also be established in municipalities within the GGH area.

Based on this anticipated pattern, it is recommended that a GGH Regional plan be developed to coordinate and manage these anticipated impacts. This would require studies of land, development of criteria for cemetery development, and overall guidance to support the development of official plans for municipalities within the region. It is recommended that a committee be created that includes provincial representatives, municipal representatives, Ministry of Environment and other conservation areas representatives as well. Most importantly, it should also include representatives from different religious 
groups and community resident groups in order to bring a diversity of perspectives for the development of proposed plans and policies.

\subsection{Establish Criteria to Promote Intensification of Existing Cemeteries}

In Toronto, as well as in other municipalities, dedicating land for cemetery development is an unpopular choice. Cemetery land would need to compete with more traditional land uses such as housing, employment, and etc. Since it is unlikely that the City will allocate hectares of cemetery lands for this use, it is recommended that the City in collaboration with the cemetery industry (including religious institution) undergo a cemetery needs analysis and to identify opportunities where intensification of existing cemetery lands may be able to provide more supply.

Encouraging untapped supply of existing cemetery land will increase the longevity of the cemetery which is beneficial for both Toronto residents and for the municipality. This way, there may be more options for people to be in close proximity to visit their loved ones and potentially reduce the cost of cemetery services. It is also in the interest of the municipalities to support this direction in order to avoid cemetery operations falling into the hands of the municipal government.

Some potential methods to encourage intensification would be to introduce a zoning by-law amendment to allow for increased density and height of mausoleums and columbariums. Vertical cemeteries are currently being designed and planned for in places with very tight land constraints, such as Taiwan and Singapore. Another tool used in other countries around the world is plot tenure and renewal. This means that instead of families paying once for the services and never have to deal with it again, tenure options would provide cemetery operators with the financial ability to purchase additional land for this use, 
and to maintain existing cemeteries for longer periods of time. Once the tenure for the plot has come to an end, families have the option to either pay to continue the tenure or do something else with the remains. For instance, in Hong Kong, once the tenure of 40 years has been reached, the body is removed from the grave then later cremated and turned into bead glass necklaces for the families.

\subsection{Acquire Cemetery Development through Parkland Dedication}

Toronto really values its parks and open spaces for its residents and non-residents alike. As the City grows so does pressure on these spaces and making sure that these spaces can be expanded and improved. At the same time the City recognizes that if they do not identify ways to create new parks, the existing parks would have to serve more and more people (City of Toronto, 2018). One way that the city is able to ensure that there are new parks for the future is by harnessing it's abilities to harness growth through Section 42 of the Planning Act. This allows the City of Toronto to require all development to contribute to the expansion and enhancement of the city's parks and open space system.

The City of Toronto recognizes existing cemeteries as parks and open spaces. Thus, there is an opportunity to extend this policy tool to the improvement, expansion, or development of new cemeteries. This could be in the form of using the tool to purchase new land for cemetery development or cash in lieu that could be used towards cemetery development by the City. This may serve as a dual benefit of having not only green space in the city but also addressing the need to accommodate the dead.

This would require a formal recognition and protocol to transfer these funds for cemetery use that is separate from park systems. This recommendation could also potentially give the municipality more leverage by applying specific zoning by-laws that can encourage intensification, use of materials, method 
of accommodating the dead, and specific design guidelines. This can create places of interest, tourist attraction, places for relaxation, and serve several other functions that are complementary to traditional parks and open spaces.

\subsection{Future Research Areas}

Planning for strong, healthy, and sustainable communities is a conversation that ought to go beyond only planning for the accommodating the needs of living. Planning should consider the full cycle of life, which also means that we must also plan for what happens once we've passed on. Death is the only certainty we have in life and it is important that cities have the infrastructure, political framework, and policy tools to meet the inevitable. Practices and traditions related to accommodating for the deceased in a multi-faith and cultural city such as Toronto is complex and rooted within a much larger planning framework. Accommodating for the deceased cannot be separated from difficult conversations around inequality, affordability and access, multicultural planning, urban sprawl, immigration, and cultural heritage. Which means that cemetery planning is not simply about providing more supply to meet future needs, but one that is about anchoring immigrant communities and giving people access to accommodate their loved ones in a place they call home.

Given the limited research available on this topic, there is untapped potential for several different areas for research. There are three overarching areas for further research - increase supply; design, and more primary data - that will be discussed below: 


\section{Challenge the Traditional 'Modern' Cemetery}

The design, layout, and features of cemeteries are characteristics that were developed based on landscape architectural norms from the 1800s. When addressing needs to develop new cemeteries, there is an opportunity to explore alternative forms, characteristics, designs, and styles that could aim to serve two main purposes: First, maximize available space, and secondly, to challenge the cemetery norm to create public open spaces for both memorialization, art, and break down the taboos around death.

Future areas for research can include examining alternative methods for accommodating the deceased by focusing on methods of memorialization. This can be complemented with primary research to gain a sense for people's perceptions and acceptance of alternative methods for memorialization and accommodating the deceased. This research can inform ways that parkland dedication can serve both functions of accommodating the deceased and providing park spaces in a City that is struggling to do both.

\section{Cemetery Needs Analysis}

Planners and decision makers need data and evidence to make informed land use planning decisions. Through a cemetery needs analysis, a more detailed picture of the issue at hand would provide clearer insight into the remaining cemetery land, and identify criteria to establish new cemetery land. Through this analysis, future research can support the identification of new sites for cemetery development within Toronto which be utilized during Official Plan reviews and comprehensive zoning by-laws. 


\section{Activating, Inactive Cemeteries}

Among the 206 cemeteries in Toronto, only 23 of them are active. Further research that examines the reasons why cemeteries became inactive in Toronto could shed light into the struggles and challenges the cemetery industry has in addressing the growing demand. Furthermore it can identify opportunities, strategies, and governing bodies that could support re-activating these spaces that could be translated to cemeteries across the province.

\section{Social Justice and Equity}

Access and affordability to cemetery services in Toronto raises issues around equity and inclusion. This is a topic that requires further research to understand how different religious and cultural groups are being impacted. Research understanding the dynamics of immigration, anchoring communities, and final resting place, parallel to issues to affordability and access can shed light into the experiences that are happening today and identify ways to challenge this issue so that cemeteries become a place where everyone has an opportunity to have Toronto as their final resting place. 


\subsection{References}

Agrawal, S.K., \& Hathiyani, A. (November 4, 2007). Funeral and Burial Sites, Rites and Rights in Multicultural Ontario. Our Diverse Cities. (134-138). Katherine Graham and Carleton University (Eds.)

file:///C:/Users/user/Downloads/Agrawal\%20and\%20Hathiyani-Funeral\%20and\%20burial\%20is sues\%20(1).pdf

Ansari, H. (2007). 'Burying the dead': making Muslim space in Britain. Historical Research, 80, 120

Bennett, G., \& Davies, P.J. (2015). Urban cemetery planning and the conflicting role of local and religious interests. Land Use Policy, 42, 450-459.

Bereavement Authority of Ontario (BAO). (2018). About the BAO. Retrieved from: https://thebao.ca/home/about-the-bao/

Canofi, P., Marini, G., \& Scaramozzino, P. (2017). The importance of being remembered: Prices for cemetery plots in the US. Economic Modelling, 64, 638-645

City of Toronto. (2016). City of Toronto Cemetery Needs Analysis.

City of Toronto. (2018). Parkland Dedication. Retrieved from: https://www.toronto.ca/citygovernment/planning-development/application-forms-fees/building-toronto-together-adevelopment-guide/parkland-dedication/

Coopper, C. (July 17, 2017). The Muslim-cemetery vote and the challenges of diversity. Montreal Gazette. Retrieved from:

http://montrealgazette.com/opinion/celine-cooper-the-muslim-cemetery-vote-and-thechallenges-of-diversity

Coutts, C., Basmajian, C., \& Chapin, T. (2011). Projecting landscapes of death. Landscape and Urban Planning, 102, 254-261.

Francis, D.; Kellaher, L.; \& Neophytou, G. (2000). Sustaining cemeteries: the use perspective. Mortality, 5(1), 34-52.

Friesen, J., \& Cardoso, T. ( 2017, November 12). Census 2016: Western provinces' populations are the fastest-growing in Canada. The Globe and Mail. Retrieved from https://www.theglobeandmail.com/news/national/census-2016-statscan 
/article33931243/

Hussein, I., \& Rugg, J. (2003). Managing London's dead: a case of strategic policy failure. Mortality, 8. (2).

Klaufus, C. (2016). "The dead are killing the living": Spatial justice, funerary services, and cemetery land use in urban Colombia.

Kymlicka, Will. 2009. The current state of multiculturalism in Canada. Canadian Journal of Social Research, 2(1), 15-34.

McGrath, J. M. (2016, October 28). In Toronto, even the dead are paying too much for real estate. TVO. Retrieved from: https://vo.org/article/current-affairs/the-next-ontario/in-toronto-even-the-dead-are-paying-toomuch-for-real-estate

Ontario, Ministry of Municipal Affairs and Housing. (November 25, 2015). Official Plans. Retrieved from: http://www.mah.gov.on.ca/Page1759.aspx

Ontario, Ministry of Municipal Affairs and Housing. (June 22, 2017). Greenbelt Plan, 2017. Retrieved from: http://www.mah.gov.on.ca/Page13783.aspx

Ontario, Ministry of Municipal Affairs and Housing. (May 7, 2017). Growth Plan for the Greater Golden Horseshoe, 2017. Retrieved from:

http://placestogrow.ca/index.php?option=com_content\&task=view\&id=430\&ltemid=14\#toc

Larkin, M. (2011). An Analysis Of Land Use Planning Policies For Cemeteries In Ontario. Major Research Paper. Ryerson University.

Laidlaw, S. (2008, April 19). Jewish History in Stone. The Star. Retrieved from: https://www.thestar.com/life/2008/04/19/jewish_history_in_stone.html

LEES + Associates. (2016). York Region Cemetery Needs Analysis and Policy Framework.

Mount Pleasant Group. (2018). About Us. 200 Years of Care. Retrieved from: http://www.mountpleasantgroup.com/About-Us.aspx

Naomi De Sousa, A. (January 21, 2015). Death in the city: what happens when all our cemeteries are full?. The Guardian. Retrieved from: https://www.theguardian.com/cities/2015/jan/21/death-in-the-city-what-happens-cemeteriesfull-cost-dying 
Nurse, D. (2001, June 19). Muslim's cemetery request on planner's agenda. Atlanta Journal Constitution. IJJ

Ontario. (February 15, 2017). Rules for the bereavement sector and burial sites. Retrieved from: https://www.ontario.ca/page/rules-bereavement-sector-and-burial-sites

Queen, L. (2016, May 5). York Region municipalities in urgent need of cemetery land. York Region. Retrieved from:

https://www.yorkregion.com/news-story/6528792-york-region-municipalities-in-urgent -need-ofcemetery-land/

Santora, Marc. (2010, August, 13). City Cemeteries Face Gridlock. New York Times. Retrieved from: https://www.nytimes.com/2010/08/15/realestate/15cov.html

Smee, Mike. (2016, September 8). Committee votes to bury study on cemetery needs. CBC News. Retrieved from: http://www.cbc.ca/news/canada/toronto/committee-votes-to-bury-study-on-cemetery-needs1.3754060

Smart, S. (2011). A Better Place: Death and Burial in Nineteenth-Century Ontario. Toronto: Dundurn Press.

Statistics Canada (2017). Immigration and ethnocultural diversity: Key results from the 2016 Census. Retrieved from: http://www.statcan.gc.ca/daily-quotidien/171025/dq171025b-eng.htm 